\title{
Impact of Pre-Treatments on the Acrylamide Formation and Organoleptic Evolution of Fried Potato Chips
}

\author{
${ }^{1}$ Samir Abdel-Monem Ahmed Ismial, \\ ${ }^{1}$ Rehab Farouk Mohammed Ali, ${ }^{2}$ Mohsen Askar and ${ }^{1}$ Wafaa Mahmoud Samy \\ ${ }^{1}$ Department of Biochemistry, Faculty of Agriculture, Cairo University, 12613, Giza, Egypt \\ ${ }^{2}$ Department of Microbial Biotechnology, National Research Centre, Dokki, Cairo, Egypt
}

Received 2013-04-02, Revised 2013-04-10; Accepted 2013-04-25

\begin{abstract}
The main objective of this investigation was to study the effect of different pre-frying treatments on reduction of acrylamide formation of fried potato Moreover; the impact of different phenol compounds and leaves on acrylamide formation was evaluated. In addition, the effects of these treatments on the sensorial quality of fried potato chips were studied. Results showed that blanching process caused significant decreases in acrylamide content of fried potato. The highest decrease was observed for those samples blanched in $\mathrm{MgCl} 2(0.1 \mathrm{M})$, L-cysteine $(0.05 \mathrm{M})$ and $0.01 \mathrm{M}$ of citric acid solutions, 97.97, 97.17 and $93.43 \%$, respectively. Soaking of potato slices in water or different solutions significantly reduced the formation of acrylamide. The decreases in acrylamide content ranged from 61.61 to $97.47 \%$. Soaking in crude, semipurified asparaginase solutions, blanching in hot water plus immersing in the enzyme solutions and soaking in phenolic acid solutions caused significant reduction in the formation of acrylamide of potato chips. Addition of fresh leaves into frying oil significantly influenced acrylamide formation. Oregano, rosemary, bamboo, guava and olive leaves caused the greatest reductions. Potato slices blanched in distilled water at $65^{\circ} \mathrm{C}, \mathrm{NaCl}$, $\mathrm{Mg} \mathrm{Cl} 2$ and $0.1 \mathrm{M}$ glutamine had significantly the highest scores of overall acceptability.
\end{abstract}

Keywords: Acrylamide, Potato, Blanching, Soaking, Protein, Antioxidants

\section{INTRODUCTION}

Potato (Solanum tuberosum) is one of the world's major agricultural crops and it is consumed daily by millions of people from diverse cultural backgrounds. Potatoes are always cooked before consumption traditionally by frying and other cooking methods (Pedreschi et al., 2006). Deep fat frying is extensively used in food processing both industrially and at home and fried potato products are one of its largest applications (Pedreschi et al., 2007). Acrylamide is a chemical compound that is formed from food components during heat treatment (frying, baking, roasting and extrusion) as a result of the Mailard's reaction between asparagine and reducing sugars (Pedreschi et al., 2004). Acrylamide shows a variety of adverse effects in animals and humans. It is known to be neurotoxic (causing peripheral neuropathy) in humans and a reproductive toxic agent in rodents (Tritscher, 2004). Acrylamide is positive in a number of tests for genotoxicity, inducing chromosomal aberrations, micronuclei, sister chromatid exchange, polyploidy, aneuploidy and other mitotic disturbances in mammalian cells in the absence of metabolic activation (Tritscher, 2004).

Acrylamide formation in foods is influenced by several factors, including processing temperature, time, content and species of reducing sugars and amino acids, $\mathrm{pH}$, moisture content and frying oils, indicating that 
acrylamide in foods can be decreased by changing processing technology (Ciesarova et al., 2006). Ferulic acid, hydrogen peroxide, ferulic acid combined with $\mathrm{H}_{2} \mathrm{O}_{2}$ or $\mathrm{Fe}^{2+}$, tea catechin, $\mathrm{NaHCO}_{3}$ and $\mathrm{NaHSO}_{3}$ were used to test the eliminating capacity for acrylamide under different temperatures and it was found that combination of ferulic acid with $\mathrm{H}_{2} \mathrm{O}_{2}$ or $\mathrm{Fe}^{2+}$ showed highest efficiency for eliminating acrylamide (Ou et al., 2004). Also, (Levine and Smith, 2005) found that $\mathrm{NaHCO}_{3}$, $\mathrm{NH}_{4} \mathrm{HCO}_{3}$, cysteine, sodium bisulfite and ascorbate could eliminate acrylamide; and citric acid, ferulic acid and $\mathrm{NaCl}$ decreased the amount of acrylamide produced. In addition, pre-treatment with the enzyme L-asparaginase is sufficient to reduce acrylamide content, since Lasparagine is considered to be one of the main precursors for the acrylamide formation in foods (Friedman, 2003).

The main objective of this investigation was to study the effect of different pre-frying treatments on reduction of acrylamide formation of fried potato chips including soaking in water and different solutions (organic acids, salts and amino acids); blanching in hot distilled water with different solutions (citric acid, salts and amino acids) as well as blanching followed by soaking. Moreover, the impact of different phenolic compounds and leaves on acrylamide formation was evaluated. In addition, the effects of these treatments on the sensorial quality of fried potato chips were studied.

\section{MATERIALS AND METHODS}

\subsection{Materials}

Potatoes (Solanum tuberosum L.) of the variety Hermas were obtained from Chipsy for Food Industries Co. Giza, Egypt. Sunflower oil was obtained from Arma for Food Industries, 10th of Ramadan, Egypt. Pseudomonas aeruginosa 50071 bacteria obtained from Microbiological Resource Center, Ain-Shams University, Cairo, Egypt. All reagents and chemicals that were used in this study were of analytical grade.

\subsection{Methods}

\subsubsection{Induction of Crude Enzyme from Pseudomonas Aeruginosa 50071 Bacteria}

A pure culture of Pseudomonas aeruginosa 50071 was maintained on tryptic soy agar slants (30 $\mathrm{g}$ of Tryptic Soy Broth (TSB) per liter, 1.5\% agar) and was subcultured regularly. To prepare an inoculum, a loopful of cells from an agar slant was first transferred into a test tube containing $10 \mathrm{~mL}$ of TSB and incubated at $37^{\circ} \mathrm{C}$ for
$18 \mathrm{~h}$ (Chayabutra and $\mathrm{Ju}, 2000$ ). About $0.5 \mathrm{~mL}$ of freshly grown single colonies of the isolates were picked up, with an inoculation loop and stirred into 50 $\mathrm{mL}$ tryptone soy broth in $250 \mathrm{~mL}$ Erlenmeyer flasks. The culture flasks were incubated at $37^{\circ} \mathrm{C}$ for 4 days. The cell free supernatant was obtained after a centrifugation at $8000 \mathrm{rpm}$ for $20 \mathrm{~min}$ and used as crude enzyme after determination of enzyme.

\subsection{Purification of the Crude Enzyme}

The method of (El-Bessoumy et al., 2004) was used for the enzyme purification. The Production media was centrifuged at $10,000 \mathrm{rpm}$ for $12 \mathrm{~min}$ to obtain the supernatant. The supernatant was saturated with $80 \%$ ammonium sulfate. The mixture was left for $12 \mathrm{~h}$ at $4^{\circ} \mathrm{C}$, followed by centrifugation at $8,000 \mathrm{rpm}$ for $20 \mathrm{~min}$ at $4^{\circ} \mathrm{C}$. The precipitate was dissolved in a $0.01 \mathrm{M}$ phosphate buffer pH 8.5 and dialyzed overnight against the same buffer at $4^{\circ} \mathrm{C}$ to obtain the Semi-purified enzyme, then the specific activity of enzyme was measured.

\subsection{Preparation of Potato Chips}

\subsubsection{Potato Chips (Slices)}

Potato tubers were washed under running water, hand-peeled and cut into round slices $(5 \mathrm{~cm}$ diameter, $2 \mathrm{~mm}$ thickness).

\subsection{Blanching Treatments}

Blanching was done by immersing the potato slices in distilled water $\left(65\right.$ and $\left.85^{\circ} \mathrm{C}\right)$, citric acid solutions (0.01 and $0.05 \mathrm{M}), \mathrm{CaCl}_{2}, \mathrm{MgCl}_{2}$ and $\mathrm{NaCl}(0.1 \mathrm{M})$ solutions as well as amino acids solutions (glycine, Larginine, L-glutamine, $0.1 \mathrm{M}$ ) and L-cysteine (0.1; $0.05 \mathrm{M})$. Samples were removed after $5 \mathrm{~min}$. The product: solution ratio was 1:5 (w/w). After blanching, potato slices were cooled in ice water for $10 \mathrm{~min}$. The blanched slices were drained and fried at $190 \pm 5^{\circ} \mathrm{C}$.

\subsection{Soaking Treatments}

Potato slices were soaked in running tap water $(15$ $\mathrm{min})$, distilled water $(60 \mathrm{~min})$, citric acid (0.01 and $0.05 \mathrm{M})$; acetic $\operatorname{acid}(0.15,0.3$ and $0.45 \mathrm{M})$ solutions, salt solutions, $0.1 \mathrm{M}\left[\mathrm{CaCl}_{2}, \mathrm{MgCl}_{2}\right.$ and $\left.\mathrm{NaCl}\right]$, amino acids solutions (glycine, L-arginine and L-glutamine, $0.1 \mathrm{M})$, L-cysteine $(0.1 ; 0.05 \mathrm{M})$ solution, $2 \%$ protein (chickpea and egg albumin) solutions and phenolic (ferulic acid, protocatechoic acid, caffeic acid, catechin and gallic acid) solutions, $(1: 10, \mathrm{w} / \mathrm{v})$ for 60 $\min$ at room temperature $\left(25^{\circ} \mathrm{C}\right)$. The soaked slices were drained and fried at $190 \pm 5^{\circ} \mathrm{C}$. 


\subsection{Addition of Different Fresh Leaves with into Frying Sunflower Oil}

Guava, rosemary, oregano, olive, cranberry and green tea leaves were added into sunflower oil during frying process at level $(5 \%)$.

\subsection{Blanching Followed by Soaking Treatments}

Potato slices were blanched in distilled water at $85^{\circ} \mathrm{C}$ for $5 \mathrm{~min}$, the blanched potato were drained and divided into two portions. A portion of the drained blanched potato was soaked in crude enzyme solution (specific activity, 46.57 units) at $37^{\circ} \mathrm{C}$ for $60 \mathrm{~min}$. A second portion of the blanched potato was soaked in semipurified enzyme solution (specific activity, 232.84 units) at $37^{\circ} \mathrm{C}$ for $60 \mathrm{~min}$. All treated potatoes were drained and fried at $190 \pm 5^{\circ} \mathrm{C}$ for $6 \mathrm{~min}$.

\subsection{Frying Conditions}

Sunflower oil $(500 \mathrm{~g})$ was placed in a stainless steel pan of electric fryer $(20 \mathrm{~cm}$ depth $\times 20 \mathrm{~cm}$ length $\times 10$ $\mathrm{cm}$ ) and heated at $190^{\circ} \mathrm{C} \pm 5^{\circ} \mathrm{C}$. Then, $100 \mathrm{~g}$ of potato slices of each treatment were fired for $6 \mathrm{~min}$.

\subsection{Determination of Total Polyphenols}

\subsubsection{Preparation of Leaves Juice}

Fresh leaves of guava, rosemary, oregano, olive, cranberry and green tea were cleaned, cut into pieces and then pressed by means of the hydraulic laboratory press model C S/N 37000-156 Freds from Carver (WI, USA). The resultant crude juices were centrifuged at $4000 \mathrm{rpm}$ for $30 \mathrm{~min}$ at $4^{\circ} \mathrm{C}$; the supernatant was concentrated at $45^{\circ} \mathrm{C}$ using a rotary evaporator (Laborota 4000 -efficient, Heildolph, Germany). The obtained juice was kept in light-protected containers at $-18^{\circ} \mathrm{C}$ until further use.

Total polyphenols were determined according to the method of (Jayaprakasha et al., 2003). An aliquot of leaves juice $(0.1 \mathrm{~mL})$ was dissolved in a $10 \mathrm{~mL}$ mixture of acetone and water $(6: 4 \mathrm{v} / \mathrm{v})$. Sample $(0.2 \mathrm{~mL})$ was mixed with $1.0 \mathrm{~mL}$ of ten-fold diluted Folin-Ciocalteu reagent and $0.8 \mathrm{~mL}$ of $75 \mathrm{~g} \mathrm{~L}^{-1}$ sodium carbonate solution. After standing for $30 \mathrm{~min}$ at room temperature, the absorbance was measured at $725 \mathrm{~nm}$. Phenolic contents were calculated on the basis of the standard curve for Gallic Acid (GAL). The results were expressed as $\mathrm{mg}$ gallic acid/100 $\mathrm{g}$.

\subsection{Determination of Free Radical Scavenging Activity (DPPH)}

The antioxidant activity of fresh leaves juice was evaluated by using the 2, 2'Diphenylpicrylhydrazyl
(DPPH) assay (Cuendet et al., 1997; Burits and Bucar, 2000). Fifty microliters of the juice were added to $5 \mathrm{~mL}$ of $0.004 \%(\mathrm{w} / \mathrm{v}) \mathrm{DPPH}$ in methanol $(100 \% \mathrm{v} / \mathrm{v})$. After, $30 \mathrm{~min}$ incubation period at room temperature the absorbance at $517 \mathrm{~nm}$ was compared to DPPH in methanol without sample (blank). The percent inhibition of free radical formation (I\%) was calculated as follow:

$$
\mathrm{I} \%=\left(\mathrm{A} \mathrm{blank}_{\mathrm{at517}}-\mathrm{A} \mathrm{sample}_{\mathrm{at517}} / \mathrm{A} \mathrm{blank}_{\mathrm{at5} 17}\right) \times 100
$$

\subsection{Determination of Acrylamide in Potato Samples}

The homogenized sample $(5 \mathrm{~g})$ was extracted with 50 $\mathrm{mL}$ of methanol $(5 \%)$ and shaked by hand for $30 \mathrm{~min}$. After centrifugation for $30 \mathrm{~min}$ at $9,000 \mathrm{rpm}$, the supernatant solution was transferred to a $200-\mathrm{mL}$ separating funnel and the aqueous layer was collected and used for analysis. The aqueous layer was centrifuged at 13 $000 \mathrm{rpm}$ for $5 \mathrm{~min}$. The pooled supernatant was filtered through a $0.2 \mu$ PVDF syringe filter. The C18 SPE column (strong cation exchange, $0.5-1.5 \mathrm{~g}$ sorbent, 0.6 mequiv. $\mathrm{g}^{-1}$ ) was conditioned with $5 \mathrm{~mL}$ methanol and the extract $(2 \mathrm{~mL})$ was loaded with $5 \mathrm{~mL}$ of water onto the column. The extracts were eluted with $2 \mathrm{~mL}$ of water. The eluent was collected for HPLC analysis.

The samples were analyzed using HPLC (Hewlett Packard 1050) with a C18 column $(250 \times 4.6 \mathrm{~nm}, 5 \mu$ purity $\mathrm{C} 18)$. The injected volume was $20 \mu \mathrm{L}$. The separation was carried out using $80 \%$ methanol/water (v/v) with flow rate $1 \mathrm{~mL} \mathrm{~min}{ }^{-1}$ and the effluent of the column was continuously monitored with the UV detector at $254 \mathrm{~nm}$ (Geng et al., 2010).

\subsection{Organoleptic Evolution of Potato Chips}

The sensory evaluation of fried potato chips were conducted two times and the mean score values was reported in the text. The potato chip samples were rated on a 10-point scale $(1,2$ : bad,3,4: poor,5,6: fair,7,8: good and 9,10: excellent).

The potato chips from each treatment, placed randomly in codified plates with 3-digit codes, were served to each panelist. Judges were placed in different places to avoid communication during the evaluation and asked to score chips for taste, texture, appearance, color, odor and overall acceptability (Carpenter et al., 2000).

\subsection{Statistical Analysis}

Data were statistically analyzed in completely randomized design in factorial arrangement according to the procedures outlined by (Gomez and Gomez, 1984) and 
the treatments means were compared by Least Significant Differences (LSD) and Duncan multiple range using SPSS program package. Data are presented in text and tables as means of three determinations.

\section{RESULTS AND DISCUSSION}

\subsection{Effect of Different Blanching Treatments on the Formation of Acrylamide in Potato Chips}

Table 1 shows the effect of different blanching treatments on the formation of acrylamide of potato chips. These result show that the formation of acrylamide was higher in control than in blanched samples. Blanching process caused significant $(\mathrm{p} \leq 0.05)$ decreases in acrylamide content. These reductions ranged from 73.58 to $97.97 \%$. Blanching reduces the formation of acrylamide of French fries probably due to the leaching out of reducing sugars, previous to frying, inhibiting in this way non-enzymatic browning reactions and leading to lighter and less red French fries (Pedreschi and Moyano, 2005). Lightness of French fries decreased as the acrylamide formation increased since the pieces get darker as a result of Maillard reactions. The highest decrease was observed for those samples blanched in $\mathrm{MgCl}_{2}(0.1 \mathrm{M})$, L-cysteine $(0.05 \mathrm{M})$ and $0.01 \mathrm{M}$ of citric acid solutions, $97.97,97.17$ and $93.43 \%$, respectively. Recently, evidence was found that cations such as $\mathrm{Ca}^{2+}$ or $\mathrm{Mg}^{2+}$ would change the reaction path from the Maillard reaction toward dehydration of glucose (Gokmen and Senyuva, 2007). Some authors diminished acrylamide formation in fried snacks products by adding amino acids, such as lysine, glycine and cysteine (Kim et al., 2005). The addition of glycine or glutamine during blanching of potato chips reduced the amount of acrylamide by almost $30 \%$ compared to control (Claeys et al., 2005). Acrylamide formation can be reduced significantly as well by introducing other amino acids, such as cysteine, lysine, or glycine, which would compete with asparagine for the carbonyl compounds in the Maillard reaction and/or enhance acrylamide elimination (Claeys et al., 2005). The nucleophilic sulphur atom of L-cysteine and the amino groups of the other amino acids might readily give rise to Michael type addition reactions with acrylamide (Fennell et al., 2005; Stadler et al., 2004). Average acrylamide contents for potato chips immersed in $\mathrm{MgCl}_{2}$ $(0.1 \mathrm{M})$, L-cysteine $(0.05 \mathrm{M})$ and $0.01 \mathrm{M}$ of citric acid solutions were 40,56 and $130 \mu \mathrm{g} 100^{-1} \mathrm{~g}$ of fried potato chips, respectively. For these treatments, acrylamide content was lower than the maximum permissible level of WHO (2005) $(0.3-2 \mu \mathrm{g} / \mathrm{kg} /$ day for the general population, body weight $70 \mathrm{~kg}$ ). Blanching of potato chips in hot water $\left(65\right.$ and $\left.85^{\circ} \mathrm{C}\right)$ or solutions containing $0.05 \mathrm{M}$ citric acid, $0.1 \mathrm{M} \mathrm{CaCl}_{2}$ or $\mathrm{NaCl}, 0.1 \mathrm{M}$ glycine, L-glutamine or L-cysteine reduced significantly acrylamide formation of potato chips by $90.40,88.88$, $90.40,73.58,76.91,85.20$ and $76.96 \%$ respectively Table 1. However, acrylamide contents of those samples were higher than the maximum permissible level of WHO (2005). The reduction of acrylamide formation in potato chips blanched in citric acid solutions may be attributed to both $\mathrm{pH}$ lowering and leaching out of free asparagine and the reducing sugars from the surface layer of potato slices to the solutions (Jung et al., 2003). Additionally, (Gokmen and Senyuva, 2007) showed that dipping of potato stips into calcium chloride solution inhibited the formation of acrylamide by up to 95\%during frying. The reduction of acrylamide formation in potato chips immersed in sodium chloride and calcium chloride solutions may be due to its complexation with amines and some intermediates of the Maillard reaction products, especially acrylic acid, a prevalently recognized precursor for forming acrylamide (Stadler et al., 2004). Also $\mathrm{Na}+$ or $\mathrm{Ca} 2+$ was indicated to interact with asparagine to prevent the formation of acrylamide (Park et al., 2005; Lindsay and Jang, 2005; Gokmen and Senyuva, 2007). Yet, in the previous study, $\mathrm{NaCl}$ did not lower the final acrylamide content in the potato model system (Mestdagh et al., 2007). On the other hand, the addition of $\mathrm{NaCl}, \mathrm{CaCl} 2$ or citric acid might also change the oil uptake (Bunger et al., 2003; Rimac-Brncic et al., 2004; Pedreschi et al., 2007). This could therefore be an additional factor, possibly influencing the formation of acrylamide in fried foodstuffs.

\subsection{Effect of Different Soaking Treatments}

Soaking of potato slices in water or different solutions caused significant reduction in the formation of acrylamide. The decreases in acrylamide content ranged from 61.61 to $97.47 \%$. Some authors reported that the reduction of the sugar content by soaking could decrease acrylamide concentration by about $60 \%$ in potato chips (Haase et al., 2003; Pedreschi et al., 2004). Potato slices treated with running water for $15 \mathrm{~min}$ and distilled water for $60 \mathrm{~min}$ showed a reduction of acrylamide formation of 61.61 and $63.63 \%$, respectively. Soaking process leads to a higher leaching of one important acrylamide precursor such as glucose that finally results in lower acrylamide formation (Pedreschi et al., 2004). These results are coincident with those of (Jung et al., 2003) who reported that dipping potato strips in distilled water for $1 \mathrm{~h}$ induced almost $25 \%$ reduction of acrylamide formation in French fries after frying at $190^{\circ} \mathrm{C}$. 
Table 1. Effect of different blanching treatments on the formation of acrylamide $(\mu \mathrm{g} / \mathrm{Kg})$ in potato chips fried at $190^{\circ} \mathrm{C} \pm 5^{\circ} \mathrm{C}$ for 6 min compared with maximum permissible level WHO (2005)*

\begin{tabular}{|c|c|c|c|}
\hline Blanching treatments (for $5 \mathrm{~min}$ at $65^{\circ} \mathrm{C}$ ) & Acrylamide content & Reduction $(\%)$ & Status \\
\hline Control (without blanching) & $1980^{\mathrm{a}} \pm 104$ & - & + \\
\hline \multicolumn{4}{|l|}{ Blanching in distilled water } \\
\hline At $65^{\circ} \mathrm{C}$ & $164^{\mathrm{ef}} \pm 16$ & 91.70 & + \\
\hline At $85^{\circ} \mathrm{C}$ & $405^{c} \pm 24$ & 79.54 & + \\
\hline \multicolumn{4}{|l|}{ Citric acid solution } \\
\hline $0.01 \mathrm{M}$ & $130^{\mathrm{efg}} \pm 52$ & 93.43 & - \\
\hline $0.05 \mathrm{M}$ & $190^{\mathrm{de}^{2}} \pm 30$ & 90.40 & + \\
\hline \multicolumn{4}{|l|}{ Salt solution $(0.1 \mathrm{M})$} \\
\hline $\mathrm{CaCl}_{2}$ & $220^{\mathrm{de}} \pm 43$ & 88.88 & + \\
\hline $\mathrm{MgCl}_{2}$ & $40^{\mathrm{ef}} \pm 2$ & 97.97 & - \\
\hline $\mathrm{NaCl}$ & $190^{\mathrm{de}} \pm 34$ & 90.40 & + \\
\hline \multicolumn{4}{|l|}{ Amino acid solution $(0.1 \mathrm{M})$} \\
\hline Glycine & $523^{\mathrm{b}} \pm 63$ & 73.58 & + \\
\hline L-Glutamine & $457^{\mathrm{b}} \pm 70$ & 76.91 & + \\
\hline L- Arginine & $293^{\mathrm{d}} \pm 49$ & 85.20 & + \\
\hline L-cysteine & $456^{\mathrm{bc}} \pm 86$ & 76.96 & + \\
\hline L-cysteine $(0.05 \mathrm{M})$ & $56^{\mathrm{ef}} \pm 8.71$ & 97.17 & - \\
\hline $\mathrm{LSD}=90.21$ & & & \\
\hline
\end{tabular}

$(+,-)$ Daily intake $(\mu \mathrm{g})$, based on consumption of $100 \mathrm{gm}$ of fried potato strips per day, was higher or lower than maximum permissible level of WHO limit $(0.3-2 \mu \mathrm{g} / \mathrm{kg} /$ day for the general population, body weight $70 \mathrm{~kg})$, respectively. ${ }^{*}$ Maximum permissible level of WHO (2005) at range of $21-140 \mu \mathrm{g} / 70 \mathrm{~kg} /$ day for the general population. Data are expressed as mean \pm SD. Values given represent means of three determinations. Values followed by the same letter are not significantly different $(p<0.05)$

Table 2. Influence of different soaking treatments on the formation of acrylamide $(\mu \mathrm{g} / \mathrm{Kg})$ in potato chips fried at $190^{\circ} \mathrm{C} \pm 5^{\circ} \mathrm{C}$ for 6 min compared with maximum permissible level WHO (2005)*

\begin{tabular}{|c|c|c|c|}
\hline Soaking treatments at room temperature for $60 \mathrm{~min}$ & Acrylamide content & Reduction (\%) & Status \\
\hline Control (without soaking) & $1980^{\mathrm{a}} \pm 104$ & - & + \\
\hline \multicolumn{4}{|l|}{ Soaking in water } \\
\hline Running water (15 min) & $760^{\mathrm{b}} \pm 127$ & 61.61 & + \\
\hline Distilled water (60 min) & $720^{\mathrm{bc}} \pm 36$ & 63.63 & + \\
\hline \multicolumn{4}{|l|}{ Organic acid } \\
\hline Citric acid $(0.01 \mathrm{M})$ & $50^{\mathrm{h}} \pm 5$ & 97.47 & - \\
\hline Citric acid $(0.05 \mathrm{M})$ & $60^{\mathrm{gh}} \pm 15$ & 96.96 & - \\
\hline Acetic acid $(0.15 \mathrm{M})$ & $290^{\mathrm{de}} \pm 43$ & 85.35 & + \\
\hline Acetic acid $(0.3 \mathrm{M})$ & $190^{\mathrm{efg}} \pm 26$ & 90.40 & + \\
\hline Acetic acid $(0.45 \mathrm{M})$ & $290^{\mathrm{de}} \pm 55$ & 85.35 & + \\
\hline \multicolumn{4}{|l|}{ Salt solution $(0.1 \mathrm{M})$} \\
\hline $\mathrm{CaCl}_{2}$ & $130^{\mathrm{fgh}_{ \pm 3}}$ & 93.43 & + \\
\hline $\mathrm{MgCl}_{2}$ & $218^{\mathrm{ef}} \pm 20$ & 88.98 & + \\
\hline $\mathrm{NaCl}$ & $170^{\mathrm{efgh}} \pm 36$ & 91.41 & + \\
\hline \multicolumn{4}{|l|}{ Amino acid solution $(0.1 \mathrm{M})$} \\
\hline Glycine & $298^{\mathrm{de}} \pm 34$ & 84.94 & + \\
\hline L-Glutamine & $634^{\mathrm{c}} \pm 84$ & 67.97 & + \\
\hline L-Arginine & $422^{\mathrm{d}_{ \pm}}+37$ & 78.68 & + \\
\hline L-cysteine & $621^{\mathrm{d}} \pm 44$ & 68.63 & + \\
\hline L-cysteine $(0.05 \mathrm{M})$ & $302^{\mathrm{de}} \pm 1$ & 84.74 & + \\
\hline \multicolumn{4}{|l|}{ Protein solution $(2 \%)$} \\
\hline Chickpea & $510^{\mathrm{b}} \pm 101$ & 74.24 & + \\
\hline **Egg albumin & $160^{c} \pm 10$ & 91.91 & + \\
\hline
\end{tabular}

$(+,-)$ Daily intake $(\mu \mathrm{g})$, based on consumption of $100 \mathrm{gm}$ of fried potato strips per day, was higher or lower than maximum permissible level of WHO limit $(0.3-2 \mu \mathrm{g} / \mathrm{kg} /$ day for the general population, body weight $70 \mathrm{~kg})$, respectively. * Maximum permissible level of WHO (2005) at range of 21-140 $\mu \mathrm{g} / 70 \mathrm{~kg}$ /day for the general population. Data are expressed as mean $\pm \mathrm{SD}$. Values given represent means of three determinations. Values followed by the same letter are not significantly different $(\mathrm{p}<0.05$ ). $* * 2 \%$ dry weight or $16.4 \%$ fresh weight 
Table 2 shows the effect of soaking in 0.01 and $0.05 \mathrm{M}$ of Citric acid or $0.15,0.3$ and 0.45 of acetic acid on the formation of acrylamide of potato chips. Potato slices soaked in 0.01 and $0.05 \mathrm{M}$ of Citric acid and $0.3 \mathrm{M}$ of acetic acid had significantly the lowest values of acrylamide 50, 60 and $190 \mu \mathrm{g} \mathrm{Kg}{ }^{-1}$ of fried potato. Organic acids, such as citric, acetic and L lactic acid reduced the final acrylamide content, but merely due to a reduced $\mathrm{pH}$ (Mestdagh et al., 2007). Lowering the $\mathrm{pH}$ using organic acids of the food system to reduce acrylamide generation may attribute to protonating the $\alpha$ amino group of asparagine, which subsequently cannot engage in nucleophilic addition reactions with carbonyl sources (Jung et al., 2003). Lowering the $\mathrm{pH}$ of the cut potatoes (e.g., with citric acid $0.5 \%-1.0 \%<20 \mathrm{~min}$ ) has been shown to lower the levels of acrylamide formed (Jung et al., 2003). Potato slices soaked in $0.1 \mathrm{M}$ of $\mathrm{CaCl}_{2}, \mathrm{MgCl}_{2}$ and $\mathrm{NaCl}$ solutions for $60 \mathrm{~min}$ showed significant reduction in the formation of acrylamide by 93.43, 88.98 and $91.41 \%$, respectively. $\mathrm{CaCl} 2$ showed more efficient in inhibiting acrylamide formation than $\mathrm{MgCl}_{2}$ and $\mathrm{NaCl}$. The acrylamide inhibiting mechanism for calcium may be due to its complexation with amines and some intermediates of the Maillard reaction products as reported before (Delgado-Andrade et al., 2004; O'Brien and Morrissey, 1997), especially acrylic acid, a prevalently recognized precursor for forming acrylamide (Stadler et al., 2004; Yaylayan et al., 2003). Soaking of potato slices in $0.1 \mathrm{M}$ of glycine, Lglutamine, L-arginine and L-cysteine for $60 \mathrm{~min}$ induced significant reductions of acrylamide levels in fried potato chips. However, those potatoes soaked in $0.1 \mathrm{M}$ of glycine and 0.05 of L-cysteine had the highest reduction 84.94 and $84.74 \%$, respectively. A related study showed that the addition of cysteine or lysine to an asparagine/glucose model system heated between 140 and $200^{\circ} \mathrm{C}$ significantly lowered acrylamide formation (Claeys et al., 2005).

Glycine and lysine can exert their beneficial effects by competing with asparagine for the carbonyl group of the sugar moiety and/or form adducts with acrylamide after it is formed. In principle, the $\mathrm{SH}$ group of cysteine (or other thiols) can exert its beneficial effects in two ways: it can form an adduct with acrylamide as well as undergo heat-induced $\mathrm{H}_{2} \mathrm{~S}$ elimination to form dehydroalanine $\left[\mathrm{CH}_{2}=\mathrm{CH}\left(\mathrm{NH}_{2}\right) \mathrm{COOH}\right]$. The $\mathrm{NH}_{2}$ group of asparagine can then competitively participate in addition reactions with the double bond of the dehydroalanine, as it does with acrylamide. Dehydroalanine can, in principle, also be formed by elimination of $\mathrm{H}_{2} \mathrm{O}$ from serine (Friedman, 1978). Evidently, free amino acids in foods can reduce as well as enhance acrylamide levels during processing and storage. Table 2 shows that soaking potato slices in protein solutions containing $2 \%$ Chickpea or egg albumin resulted in significantly reduced acrylamide levels in fried potato by 74.24 and $91.91 \%$ respectively. The protein content of the fried samples was inversely related to acrylamide levels. The protective effect of the chickpea proteins may be due to their known thermo stability. The heat-stable proteins appear to function as a thermal barrier of the potato slices and/or to combine with some of the acrylamide as it is formed in the food matrix during frying (Friedman and Levin, 2008; Fiselier et al., 2004) coated potato croquettes with a mixture of egg and breadcrumbs. Even though the product was browner than regular croquettes, the acrylamide content was reduced from 280 to $50 \mathrm{ppb}$.

Effect of soaking in crude (specific activity, 46.57 units) and semi-purified (specific activity, 232.84 units) asparaginase solutions and blanching plus immersing in the enzyme solutions.

Table 3 shows that enzyme treatments significantly lowered acrylamide formation by 93.93 to $97.97 \%$. Acrylamide content was lower than the maximum permissible level of WHO (2005). The application of asparaginase represents another strategy for acrylamide reduction. As in the presence of acids, asparagine is hydrolysed to aspartic acid, thus inhibiting acrylamide generation in the Maillard reaction. When the enzyme preparation was added to wheat cracker production, acrylamide levels were decreased by at least $70 \%$ without any changes in the colour or flavour of the products (Vass et al., 2004).

\subsection{Effect of Soaking in Phenolic Solutions}

Table 4 shows the effect of soaking in ferulic, protocatechoic, caffeic, gallic acids and catechin solutions on the formation of acrylamide of potato chips. Soaking in phenolic acid solutions for 60 min resulted in significant reductions in the formation of acrylamide of potato chips. These reductions ranged from 31.81 to $98.03 \%$. Gallic acid had the highest efficiency for reducing acrylamide in fried potato, 98.03. Acrylamide content was lower than the maximum permissible level of WHO (2005). Reducing agents, ferulic acid and catechin were also used to reduce acrylamide formation by inhibiting transformation of acrolein to acrylic acid proposed by (Mottram and Wedzicha, 2002). Since this mechanism was discounted by several researches (Stadler et al., 2004; Vattem and Shetty, 2003; Yaylayan et al., 2003), these two agents may have other inhibiting mechanism, for example, they form quinone at higher temperature and react with asparagine and the formed amines (Hurrel and Fiont, 1984) and therefore may decrease acrylamide production. 
Table 3. Effect of soaking in crude and semi-purified asparaginase solutions and blanching plus immersing in crude and semipurified asparaginase on the formation of acrylamide of potato chips, fried at $190 \pm 5^{\circ} \mathrm{C}$ for 6 min compared with maximum permissible level WHO (2005)*

\begin{tabular}{llll}
\hline Treatment & Acrylamide content & Reduction (\%) & Status \\
\hline $\begin{array}{l}\text { Control (without any treatment) } \\
\text { Soaking at } 37^{\circ} \mathrm{C} \text { for } 60 \mathrm{mi}\end{array}$ & $1980^{\mathrm{a}} \pm 104$ & - & \\
$\begin{array}{l}\text { Semi-purified enzyme } \\
\text { (specific activity, } 232.84 \text { units) }\end{array}$ & & & \\
Crude enzyme (specific activity, 46.57 units) & $120^{\mathrm{b}} \pm 2.0$ & 93.93 & - \\
$\begin{array}{l}\text { Blanching in hot distilled water at } 85^{\circ} \mathrm{C} \\
\text { for } 5 \text { min and followed by soaking in }\end{array}$ & $40^{\mathrm{b}} \pm 9.0$ & 97.97 & - \\
$\begin{array}{l}\text { Semi-purified enzyme, specific activity, } \\
232.84 \text { units) (at } 37^{\circ} \mathrm{C} \text { for } 60 \text { min) }\end{array}$ & & \\
Crude enzyme, specific activity, & $70^{\mathrm{b}} \pm 9.2$ & 96.46 & - \\
$\begin{array}{l}46.57 \text { units) (at } 37^{\circ} \mathrm{C} \text { for } 60 \text { min) } \\
\text { LSD }=93.0\end{array}$ & $40^{\mathrm{b}} \pm 5.8$ & 97.97 & - \\
\hline
\end{tabular}

(+,-Daily intake $(\mu \mathrm{g})$, based on consumption of $100 \mathrm{gm}$ of fried potato strips per day, was higher or lower than maximum permissible level of WHO limit (0.3-2 $\mu \mathrm{g} / \mathrm{kg} /$ day for the general population, body weight $70 \mathrm{~kg})$, respectively.* Maximum permissible level of WHO (2005) at range of 21-140 $\mu \mathrm{g} / 70 \mathrm{~kg} / \mathrm{day}$ for the general population. Data are expressed as mean $\pm \mathrm{SD}$. Values given represent means of three determinations. Values followed by the same letter are not significantly different $(\mathrm{p}<0.05)$

Table 4. Acrylamide contents $(\mu \mathrm{g} / \mathrm{Kg})$ in potato chips pre-soaked (potato: solution, 1:2) for 60 min on different phenolic solutions (70 mg $60 \mathrm{~mL}^{-1}$, in traces of tween 80 ) and fried on sunflower oil at $190^{\circ} \mathrm{C} \pm 5^{\circ} \mathrm{C}$ for 6 min comparing with maximum permissible level WHO (2005)*

\begin{tabular}{lcll}
\hline Treatments & $\begin{array}{l}\text { Acrylamide } \\
\text { content }\end{array}$ & $\begin{array}{l}\text { Reduction } \\
(\%)\end{array}$ & Status \\
\hline Control & $1980^{\mathrm{b}} \pm 104$ & - & + \\
Ferulic acid & $461^{\mathrm{c}} \pm 34$ & 76.71 & + \\
Protocatechoic acid & $1350^{\mathrm{a}} \pm 95$ & 31.81 & + \\
Caffeic acid & $528^{\mathrm{c}} \pm 143$ & 73.33 & + \\
Catechin & $180^{\mathrm{d}} \pm 26$ & 90.90 & + \\
Gallic acid & $39^{\mathrm{e}} \pm 6$ & 98.03 & - \\
LSD $=149.75$ & & &
\end{tabular}

$(+,-)$ Daily intake $(\mu \mathrm{g})$, based on consumption of $100 \mathrm{gm}$ of fried potato strips per day, was higher or lower than maximum permissible level of WHO limit $(0.3-2 \mu \mathrm{g} / \mathrm{kg} / \mathrm{day}$ for the general population, body weight $70 \mathrm{~kg}$ ), respectively.* Maximum permissible level of WHO (2005) at range of 21-140 $\mu \mathrm{g} / 70 \mathrm{~kg} / \mathrm{day}$ for the general population. Data are expressed as mean \pm SD. Values given represent means of three determinations. Values followed by the same letter are not significantly different $(p<0.05)$

\subsection{Total Phenol Content and Free Radical Scavenging Activity of Different Fresh Leaves}

Phenolic Compounds (PCs) may contribute directly to the antioxidant action; therefore, it is necessary to investigate total phenolic content. Table 5 shows total phenolic content of leaves. They varied significantly $(\mathrm{p}<0.05)$ from 577.8 to $1490.1 \mathrm{mg}$ Gallic Acid Equivalents (GAE) per $100 \mathrm{~g} \mathrm{DW}$. Granberry, guava and green tea leaves had the highest $(p<0.05)$ levels of total phenolics 1490.1, 1092 and 1020 mg Gallic Acid Equivalents (GAE) per $100 \mathrm{~g} \mathrm{DW}$, respectively.
Table 5. Total phenolic content and free radical scavenging activity of different fresh leaves

\begin{tabular}{lcc}
\hline Leaves & $\begin{array}{l}\text { Total } \\
\text { phenolic }\end{array}$ & $\begin{array}{l}\text { Free radical } \\
\text { scavenging (\%) }\end{array}$ \\
\hline Guava leaves & $1092.6^{\mathrm{b}} \pm 1.52$ & $88.7^{\mathrm{b}} \pm 1.20$ \\
Rosemary leaves & $899.5^{\mathrm{d}} \pm 1.00$ & $83.2^{\mathrm{c}} \pm 1.03$ \\
Oregano leaves & $577.8^{\mathrm{f}} \pm 0.577$ & $79.2^{\mathrm{d}} \pm 1.40$ \\
Olive leaves & $751.1^{\mathrm{e}} \pm 0.577$ & $73.2^{\mathrm{e}} \pm 1.09$ \\
Cranberry leaves & $1490.1^{\mathrm{a}} \pm 0.587$ & $42.5^{\mathrm{f}} \pm 1.01$ \\
Green tea leaves & $1020.4^{\mathrm{c}} \pm 1.00$ & $95.7^{\mathrm{a}} \pm 1.20$ \\
LSD $=$ & 1.59 & 1.64 \\
\hline
\end{tabular}

Data are expressed as mean \pm SD. Values given represent means of three determinations. Values followed by the same letter are not significantly different $(\mathrm{p}<0.05)$. Total polyphenols are expressed as $\mathrm{mg}$ gallic acid/100g

However rosemary, oregano and olive leaves contained moderate amounts of total phenolics 899.5, 577.8 and $751.1 \mathrm{mg}$ Gallic Acid Equivalents (GAE), respectively. The total phenolics content of granberry leaves was about $1.3,1.4,1.65,1.98$ and 2.57-fold greater than that of the guava, green tea, respectively. Although the granberry leaves contained the highest level of phenolics, the lowest DPPH radical scavenging activity was detected in granberry leaves. Radical Scavenging Activity (RSA) depends on the composition of phytochemicals, including antioxidatively active compounds in plants (Baltrusaityte et al., 2007). Green tea, guava leaves had the higher DPPH radical-scavenging activity 95.7 and $88.7 \%$, "respectively", followed by rosemary and oregano leaves 83.2 and $79.2 \%$, "respectively". The radicalscavenging activities of these extracts can be attributed to the presence of some compounds that 
have antioxidant activity. Baardseth et al. (2010) stated that the higher content of total phenolic compounds, the stronger antioxidant activity. Although the granberry leaves contained the highest level of phenolics, the lowest DPPH radical scavenging activity was detected in granberry leaves.

\subsection{Effect of Different Fresh Leaves into Frying Oil on Acrylamide Formation}

Table 6 shows the effect of addition of different fresh leaves into frying sunflower oil $\left(5 \mathrm{~g} 100^{-1} \mathrm{~g}\right)$ on the formation of acrylamide in potato chips fried at $190 \pm 5^{\circ} \mathrm{C}$ for $6 \mathrm{~min}$. Addition of fresh leaves into frying oil significantly influenced acrylamide formation. Oregano, rosemary, bamboo, guava and olive leaves caused the greatest reductions, of 92.8, 85.7, 84.6, 84.0 and 75.7\%, respectively, however the lowest reductions were showed for Cranberry and Green tea leaves 59.6 and $56.5 \%$, respectively. (Hedegaard et al., 2008) reported that addition of aqueous rosemary extract, rosemary oil, dried rosemary leaves to wheat dough reduced the content of acrylamide in wheat buns by $62 \%, 67$ and $57 \%$, respectively. Significant acrylamide reduction was reported by (Zhang and Zhang, 2007) in fried bread sticks upon addition of Antioxidants of Bamboo Leaves (AOB) and antioxidant from Green Tea (EGT). Levine and Smith (2005) reported a slight lowering effect upon addition of ascorbic or ferulic acid to wheat/water model systems.

\subsection{Sensory Evaluation}

Table 7 shows the effect of blanching in water or different solutions on sensorial attributes of potato chips. Potato slices blanched in distilled water at $65^{\circ} \mathrm{C}, \mathrm{NaCl}, \mathrm{MgCl} 2$ and glutamine $(0.1 \mathrm{M})$ had significantly the highest scores of taste, texture, appearance, color, odor and overall acceptability. However those blanched in distilled water at $85^{\circ} \mathrm{C}$, citric acid (0.05), L-cysteine (0.1M) had significantly the lowest values. Acidification may moreover result in a sour product taste (Kita et al., 2004; Franke et al., 2005). This effect however depends upon the applied soaking or blanching treatment and the type and concentration of the acid used. Addition of (sulphur containing) amino acids may also generate unpleasant off-flavours upon heating, which should be taken into account as well (Claeys et al., 2005). Effect of soaking in water or various solutions were shown in Table 8. These results show that soaking in citric acid $(0.3$ and $0.45 \mathrm{M}) \mathrm{CaCl}_{2}$ and L-cysteine $(0.1$ and $0.05 \mathrm{M}$ ) solutions had significantly the lowest values of taste, odor and overall acceptability. It was suggested that acetic acid would be a better acidulant for the pretreatment of potato crisps compared to citric acid, due to the less appearing sourness (Kita et al., 2004). Addition of (sulphur containing) amino acids may also generate unpleasant off-flavours upon heating, which should be taken into account as well (Claeys et al., 2005). Calcium chloride might improve product texture, but on the other hand can cause a bitter aftertaste (Varela et al., 2007). Consequently, these pre-treatments may also cause unwanted sensorial defects. While those potato slices treated with running water, distilled water, $\mathrm{NaCl}, 0.1 \mathrm{M}$ glycine, 0.1 glutamine, 0.1 arginine, chickpea and egg albumin solutions had significantly $(\mathrm{p} \leq 0.05)$ the higher values of overall acceptability with a score above 7 . The result presented in Table 9 showed that the acceptability of fried potatoes was not affected by the addition of fresh leaves into frying oil, which ensures good taste, texture, appearance, color, odor and overall acceptability of fried potato.

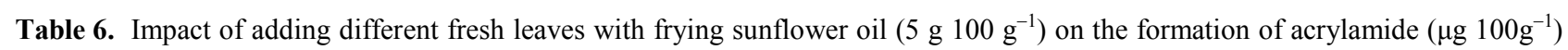
in potato chips fried at $190^{\circ} \mathrm{C} \pm 5^{\circ} \mathrm{C}$ for 6 min compared with maximum permissible level WHO (2005)*

\begin{tabular}{lclc}
\hline Treatments & Acrylamide content & Reduction (\%) & Status \\
\hline Control & $1980^{\mathrm{a}} \pm 104$ & - & + \\
Bamboo & $305^{\mathrm{d}} \pm 15.6$ & 84.6 & + \\
Guava leaves & $317^{\mathrm{d}} \pm 14.7$ & 84.0 & + \\
Rosemary leaves & $280^{\mathrm{d}} \pm 52.9$ & 85.7 & + \\
Oregano leaves & $140^{\mathrm{a}} \pm 20.0$ & 92.8 & - \\
Olive leaves & $480^{\mathrm{c}} \pm 72.1$ & 75.7 & + \\
Olive leaves (juice) & & & + \\
equivalent 5 g fresh leaves & $810^{\mathrm{b}} \pm 26.4$ & 59.0 & + \\
Cranberry leaves & $800^{\mathrm{b}} \pm 100$ & 59.6 & + \\
Green tea leaves & $860^{\mathrm{b}} \pm 35.3$ & 56.5 & + \\
LSD 101.90 & & & \\
\hline
\end{tabular}

$\mathrm{LSD}=101.90$

$(+,-$ Daily intake $(\mu \mathrm{g})$, based on consumption of $100 \mathrm{gm}$ of fried potato strips per day, was higher or lower than maximum permissible level of WHO limit $(0.3-2 \mu \mathrm{g} / \mathrm{kg} /$ day for the general population, body weight $70 \mathrm{~kg})$, respectively.* Maximum permissible level of WHO (2005) at range of $21-140 \mu \mathrm{g} / 70 \mathrm{~kg} /$ day for the general population. Data are expressed as mean \pm SD. Values given represent means of three determinations. Values followed by the same letter are not significantly different $(p<0.05)$ 
Table 7. Effect of blanching treatments on sensorial attributes of potato chips

\begin{tabular}{|c|c|c|c|c|c|c|}
\hline $\begin{array}{l}\text { Blanching treatments } \\
\text { (for } 5 \mathrm{~min} \text { at } 65^{\circ} \mathrm{C} \text { ) }\end{array}$ & Taste & Texture & Appearance & Color & Odor & $\begin{array}{l}\text { Over all } \\
\text { acceptability }\end{array}$ \\
\hline Control & $8.0^{\mathrm{a}} \pm 0.0$ & $7.8^{\mathrm{abc}} \pm 0.4$ & $7.8^{\mathrm{ab}} \pm 0.4$ & $8.0^{\mathrm{a}} \pm 0.5$ & $8.0^{\mathrm{a} \pm} 0.7$ & $7.6^{\mathrm{ab}} \pm 0.3$ \\
\hline Commercial product & $8.8^{\mathrm{a}} \pm 0.5$ & $8.4^{\mathrm{ab}} \pm 0.5$ & $8.6^{\mathrm{a}} \pm 0.5$ & $8.3^{b c} \pm 0.5$ & $8.2^{\mathrm{ab}} \pm 0.4$ & $8.5^{\mathrm{ab}} \pm 0.5$ \\
\hline Distilled water at $65^{\circ} \mathrm{C}$ & $7.8^{\mathrm{ab}} \pm 0.4$ & $8.5^{\mathrm{a}} \pm 0.5$ & $8.2^{\mathrm{a}} \pm 0.4$ & $8.2^{\mathrm{a}} \pm 0.4$ & $8.0^{\mathrm{a} \pm} 0.3$ & $7.8^{\mathrm{ab}} \pm 0.2$ \\
\hline Distilled water at $85^{\circ} \mathrm{C}$ & $6.2^{\mathrm{d}} \pm 0.4$ & $7.4^{\mathrm{bc}} \pm 1.0$ & $7.6^{\mathrm{abc}} \pm 0.5$ & $7.4^{\mathrm{a}} \pm 0.8$ & $7.8^{\mathrm{a}} \pm 0.8$ & $7.4^{\mathrm{abc}} \pm 0.8$ \\
\hline Citric acid $0.01 \mathrm{M}$ & $7.8^{\mathrm{ab}} \pm 0.4$ & $8.2^{\mathrm{ab}} \pm 0.4$ & $7.8^{\mathrm{ab}} \pm 0.4$ & $7.8^{\mathrm{a}} \pm 0.4$ & $7.2^{\mathrm{a}} \pm 0.8$ & $7.7^{\mathrm{ab}} \pm 1.0$ \\
\hline Citric acid $0.05 \mathrm{M}$ & $5.0^{\mathrm{e}} \pm 0.0$ & $6.2^{\mathrm{e}} \pm 0.5$ & $7.0^{\mathrm{cd}} \pm 0.0$ & $7.4^{\mathrm{a}} \pm 0.5$ & $7.4^{\mathrm{a}} \pm 0.5$ & $6.7^{\mathrm{bc}} \pm 0.3$ \\
\hline $\mathrm{CaCl}_{2}(0.1 \mathrm{M})$ & $7.0^{\mathrm{c} 0.0} \pm 0.0$ & $6.4^{\mathrm{de}} \pm 0.4$ & $7.6^{\mathrm{abc}} \pm 0.5$ & $7.8^{\mathrm{a}} \pm 0.4$ & $7.0^{\mathrm{a}} \pm 1.0$ & $7.2^{\mathrm{abc}} \pm 0.4$ \\
\hline $\mathrm{MgCl}_{2}(0.1 \mathrm{M})$ & $8.2^{\mathrm{a}} \pm 0.0$ & $7.2^{\text {bcd }} \pm 004$ & $8.0^{\mathrm{ab}} \pm 0.0$ & $8.0^{\mathrm{a}} \pm 0.7$ & $8.2^{\mathrm{a}} \pm 0.4$ & $8.2^{\mathrm{ab}} \pm 0.4$ \\
\hline $\mathrm{NaCl}(0.1 \mathrm{M})$ & $7.2^{\mathrm{bc}} \pm 0.4$ & $8.2^{\mathrm{ab}} \pm 0.0$ & $7.2^{\mathrm{bcd}} \pm 0.4$ & $7.4^{\mathrm{a}} \pm 0.5$ & $7.2^{\mathrm{a}} \pm 0.8$ & $7.6^{\mathrm{ab}} \pm 0.9$ \\
\hline Glycine(0.1 M) & $7.8^{\mathrm{ab}} \pm 0.4$ & $7.0^{\text {cde }_{ \pm}} \pm 0.4$ & $8.0^{\mathrm{ab}} \pm 0.0$ & $7.8^{\mathrm{a}} \pm 0.4$ & $7.8^{\mathrm{a}} \pm 0.4$ & $7.7^{\mathrm{ab}} \pm 0.5$ \\
\hline L-Glutamine(0.1 M) & $8.4^{\mathrm{a}} \pm 0.5$ & $7.2^{\mathrm{bcd}} \pm 0.0$ & $8.4^{\mathrm{a}} \pm 0.5$ & $8.0^{\mathrm{a}} \pm 0.0$ & $8.2^{\mathrm{a}} \pm 0.4$ & $8.3^{\mathrm{a}} \pm 0.8$ \\
\hline L-Arginine $(0.1 \mathrm{M})$ & $5.2^{\mathrm{e}} \pm 0.4$ & $8.0^{\mathrm{ab}} \pm 0.4$ & $6.6^{\mathrm{d}} \pm 0.5$ & $7.6^{\mathrm{a}} \pm 0.5$ & $6.0^{\mathrm{b}} \pm 0.7$ & $7.0^{\mathrm{abc}} \pm 1.0$ \\
\hline L-cysteine $(0.1 \mathrm{M})$ & $5.6^{\mathrm{e}} \pm 0.5$ & $5.2^{\mathrm{f}} \pm 0.5$ & $6.0^{\mathrm{e}} \pm 0.4$ & $5.4^{\mathrm{b}} \pm 0.4$ & $5.6^{\mathrm{b}} \pm 0.8$ & $5.6^{\mathrm{d}} \pm 0.5$ \\
\hline L-cysteine $(0.05 \mathrm{M})$ & $5.6 \mathrm{e} \pm 0.5$ & $5.4^{\mathrm{f}} \pm 0.5$ & $5.8^{\mathrm{e}} \pm 0.0$ & $6.4^{\mathrm{b}} \pm 0.5$ & $5.4^{\mathrm{b}} \pm 0.5$ & $6.2^{\mathrm{cd}} \pm 0.4$ \\
\hline $\mathrm{LSD}=$ & 0.54 & 0.66 & 0.53 & 0.68 & 0.86 & 0.89 \\
\hline
\end{tabular}

Data are expressed as mean \pm SD. Values followed by the same letter are not significantly different $(\mathrm{p}<0.05)$. The potato chip samples were rated on a 10-point scale (1,2: bad,3,4: poor, 5,6: fair,7,8: good and 9,10: excellent)

Table 8. Effect of different soaking treatments on sensorial attributes of potato chips

\begin{tabular}{|c|c|c|c|c|c|c|}
\hline $\begin{array}{l}\text { Soaking treatments at room } \\
\text { temperature for } 60 \mathrm{~min}\end{array}$ & Taste & Texture & Appearance & Color & Odor & $\begin{array}{l}\text { Over all } \\
\text { acceptability }\end{array}$ \\
\hline Control & $1.2 \pm^{\mathrm{abc}} 7.8$ & $0.8 \pm^{\mathrm{abc}} 7.4$ & $0.4 \pm^{\mathrm{abc}} 7.2$ & $0.5 \pm^{\mathrm{cd}} 7.4$ & $0.5 \pm^{\text {bcd }} 7.4$ & $0.3 \pm^{\mathrm{bcd}} 7.7$ \\
\hline Commercial product & $0.5 \pm^{\mathrm{a}} 8.8$ & $0.5 \pm^{\mathrm{a}} 8.5$ & $0.5 \pm^{\mathrm{a}} 8.6$ & $0.5 \pm^{\mathrm{bc}} 8.3$ & $0.4 \pm^{\mathrm{ab}} 8.2$ & $0.5 \pm^{\mathrm{ab}} 8.5$ \\
\hline Running water (15 min) & $0.4 \pm^{\mathrm{abc}} 7.6$ & $0.4 \pm^{\text {cde }} 6.8$ & $0.0 \pm^{\mathrm{ab}} 8.0$ & $0.0 \pm \pm^{\mathrm{bc}} 8.0$ & $0.4 \pm^{\mathrm{abcd}} 7.8$ & $0.2 \pm^{\mathrm{bcd}} 7.8$ \\
\hline Distilled water (60 min) & $0.8 \pm^{\text {bcde }} 6.4$ & $0.8 \pm^{\mathrm{abc}} 7.8$ & $0.5 \pm^{\mathrm{abc}} 7.4$ & $0.5 \pm^{\mathrm{bcd}} 7.0$ & $0.4 \pm^{\text {cde }} 7.2$ & $0.3 \pm^{\mathrm{bcd}} 7.5$ \\
\hline Citric acid $(0.01 \mathrm{M})$ & $0.8 \pm^{\text {bcde }} 6.4$ & $0.5 \pm^{\mathrm{abc}} 7.6$ & $0.8 \pm^{\mathrm{ba}} 7.6$ & $0.4 \pm^{\mathrm{bcd}} 7.8$ & $0.4 \pm^{\mathrm{abcd}} 7.8$ & $0.3 \pm^{\mathrm{bcd}} 7.5$ \\
\hline Citric acid $(0.05 \mathrm{M})$ & $0.8 \pm^{\text {bcde }} 6.8$ & $0.8 \pm^{\text {cde }} 6.6$ & $0.4 \pm^{\mathrm{ab}} 7.8$ & $0.4 \pm^{\mathrm{bcd}} 7.8$ & $0.5 \pm^{\mathrm{bcd}} 7.6$ & $0.1 \pm^{\mathrm{bcd}} 7.5$ \\
\hline Acetic acid $(0.15 \mathrm{M})$ & $1.3 \pm^{\mathrm{cde}} 6$ & $0.8 \pm^{\text {cde }} 6.6$ & $0.5 \pm^{\mathrm{ab}} 7.6$ & $0.5 \pm^{\mathrm{bcd}} 7.6$ & $0.4 \pm^{\text {cde }} 7.2$ & $0.3 \pm \pm^{\mathrm{d}} 7.2$ \\
\hline Acetic acid $(0.3 \mathrm{M})$ & $0.7 \pm^{\text {bcde }} 6.2$ & $0.0 \pm^{\text {cde }} 6.8$ & $0.8 \pm^{\mathrm{abc}} 7.4$ & $0.4 \pm^{\mathrm{bcd}} 7.8$ & $0.4 \pm^{\text {cde }} 7.2$ & $0.3 \pm^{\mathrm{cd}} 7.4$ \\
\hline Acetic acid $(0.45 \mathrm{M})$ & $1 \pm^{\text {bcde }} 6.4$ & $0.0 \pm^{\mathrm{abcd}} 7.0$ & $0.5 \pm^{\mathrm{abc}} 7.4$ & $0.4 \pm^{\mathrm{bcd}} 7.8$ & $0.5 \pm^{\mathrm{bcd}} 7.4$ & $0.4 \pm^{\mathrm{bcd}} 7.4$ \\
\hline $\mathrm{CaCl}_{2}(0.1 \mathrm{M})$ & $1.3 \pm \pm^{\text {bcde }} 6.6$ & $0.8 \pm{ }^{\mathrm{de}} 6.2$ & $0.0 \pm^{\mathrm{bc}} 7.0$ & $0.0 \pm^{\mathrm{d}} 7.0$ & $0.0 \pm^{\mathrm{de}} 7.0$ & $0.5 \pm \pm^{\mathrm{de}} 7.0$ \\
\hline $\mathrm{MgCl}_{2}(0.1 \mathrm{M})$ & $0.8 \pm^{\mathrm{abcd}} 7$ & $0.5 \pm^{\mathrm{abc}} 7.6$ & $0.8 \pm^{\mathrm{ab}} 7.6$ & $0.4 \pm^{\mathrm{bcd}} 7.8$ & $0.4 \pm^{\mathrm{abcd}} 7.8$ & $0.4 \pm^{\mathrm{de}} 7.0$ \\
\hline $\mathrm{NaCl}(0.1 \mathrm{M})$ & $1.0 \pm^{\mathrm{abcd}} 7.2$ & $0.8 \pm^{\mathrm{abc}} 7.8$ & $0.8 \pm^{\mathrm{ab}} 7.8$ & $0.0 \pm \pm^{\mathrm{bc}} 8.0$ & $0.0 \pm^{\mathrm{abc}} 8.0$ & $0.5 \pm^{\mathrm{bcd}} 7.8$ \\
\hline Glycine (0.1 M) & $0.4 \pm^{\mathrm{abcd}} 7.4$ & $0.4 \pm^{\mathrm{ab}} 8.2$ & $0.4 \pm^{\mathrm{ab}} 8.6$ & $0.5 \pm^{\mathrm{b}} 8.4$ & $0.0 \pm^{\mathrm{abc}} 8.0$ & $0.4 \pm^{\mathrm{abc}} 8.3$ \\
\hline Glutamine $(0.1 \mathrm{M})$ & $0.3 \pm^{\mathrm{ab}} 8.2$ & $0.4 \pm^{\mathrm{ab}} 8.2$ & $0.8 \pm^{\mathrm{a}} 8.6$ & $0.0 \pm^{\mathrm{a}} 9.0$ & $0.5 \pm^{\mathrm{a}} 8.6$ & $0.2 \pm^{\mathrm{a}} 8.8$ \\
\hline Arginine $(0.1 \mathrm{M})$ & $0.8 \pm^{\mathrm{e}} 5.0$ & $0.5 \pm^{\mathrm{e}} 5.6$ & $0.0 \pm^{\mathrm{bc}} 7.0$ & $0.4 \pm^{\mathrm{f}} 5.2$ & $0.8 \pm^{\mathrm{e}} 6.4$ & $1.5 \pm^{\mathrm{d}} 7.1$ \\
\hline L-cysteine $(0.1 \mathrm{M})$ & $0.2 \pm{ }^{\mathrm{de}} 5.6$ & $0.5 \pm^{\mathrm{e}} 5.6$ & $0.8 \pm^{\mathrm{d}} 5.2$ & $0.5 \pm^{\mathrm{f}} 5.4$ & $0.0 \pm^{\mathrm{g}} 5.0$ & $0.5 \pm^{\mathrm{f}} 5.6$ \\
\hline L-cysteine $(0.05 \mathrm{M})$ & $0.5 \pm^{\text {bcde }} 6.6$ & $0.4 \pm^{\text {cde }} 6.6$ & $0.6 \pm^{\mathrm{c}} 6.2$ & $0.5 \pm^{\mathrm{e}} 6.4$ & $0.2 \pm \pm^{\mathrm{f}} 5.8$ & $0.4 \pm^{\mathrm{ef}} 6.2$ \\
\hline Chickpea $(2 \%)$ & $0.8 \pm^{\text {bcde }} 6.9$ & $0.4 \pm^{\mathrm{e}} 5.6$ & $0.1 \pm^{\mathrm{bc}} 7.1$ & $0.6 \pm^{\mathrm{b}} 8.0$ & $0.4 \pm^{\mathrm{abcd}} 7.8$ & $0.6 \pm^{\mathrm{d}} 7.1$ \\
\hline Egg albumin $(2 \%)$ & $0.9 \pm^{\text {bcde }} 6.8$ & $0.5 \pm^{\mathrm{e}} 5.6$ & $0.2 \pm^{\mathrm{bc}} 7.2$ & $0.7 \pm^{\mathrm{b}} 8.1$ & $0.5 \pm^{\mathrm{de}} 7.0$ & $0.7 \pm^{\mathrm{d}} 7.0$ \\
\hline $\mathrm{LSD}=$ & 1.18 & 0.85 & 0.81 & 0.55 & 0.57 & 0.64 \\
\hline
\end{tabular}

Data are expressed as mean \pm SD. Values followed by the same letter are not significantly different $(\mathrm{p}<0.05)$. The potato chip samples were rated on a 10-point scale (1,2: bad,3,4: poor,5,6: fair,7,8: good and 9,10: excellent) 
Table 9. Effect of addition of fresh leaves into sunflower frying oil on sensorial attributes of potato chips

\begin{tabular}{|c|c|c|c|c|c|c|}
\hline $\begin{array}{l}\text { Soaking treatments at room } \\
\text { temperature for } 60 \mathrm{~min}\end{array}$ & Taste & Texture & Appearance & Color & Odor & $\begin{array}{l}\text { Over all } \\
\text { acceptability }\end{array}$ \\
\hline Control & $8.0^{\mathrm{a}} \pm 0.2$ & $7.8^{\mathrm{a}} \pm 0.4$ & $7.2^{\mathrm{ab}} \pm 0.4$ & $7.6^{\mathrm{a}} \pm 0.5$ & $7.4^{\mathrm{ab}} \pm 0.5$ & $7.5^{\mathrm{a}} \pm 0.5$ \\
\hline Commercial product & $0.5 \pm^{\mathrm{a}} 8.8$ & $0.5 \pm^{\mathrm{a}} 8.5$ & $0.5 \pm^{\mathrm{a}} 8.6$ & $0.5 \pm^{\mathrm{bc}} 8.3$ & $0.4 \pm^{\mathrm{ab}} 8.2$ & $0.5 \pm^{\mathrm{ab}} 8.5$ \\
\hline Guava leaves & $7.4^{\mathrm{a}} \pm 0.4$ & $7.6^{\mathrm{a}} \pm 0.5$ & $7.6^{\mathrm{a}} \pm 0.5$ & $7.8^{\mathrm{a}} \pm 0.4$ & $7.4^{\mathrm{ab}} \pm 0.5$ & $7.4^{\mathrm{a}} \pm 0.5$ \\
\hline Rosemary leaves & $7.4^{\mathrm{a}} \pm 0.4$ & $7.4^{\mathrm{a}} \pm 0.5$ & $6.6^{\mathrm{b}} \pm 0.8$ & $7.2^{\mathrm{a}} \pm 0.4$ & $8.0^{\mathrm{ab}^{\mathrm{b}}} \pm 1.0$ & $7.6^{\mathrm{a}} \pm 1.0$ \\
\hline Oregano leaves & $7.4^{\mathrm{a}} \pm 0.4$ & $7.8^{\mathrm{a}} \pm 0.4$ & $7.8^{\mathrm{a}} \pm 0.4$ & $7.6^{\mathrm{a}} \pm 0.5$ & $8.0^{\mathrm{ab}} \pm 1.0$ & $8.2^{\mathrm{a}} \pm 0.8$ \\
\hline Olive leaves & $6.2^{\mathrm{b}} \pm 0.8$ & $6.6^{\mathrm{a}} \pm 0.5$ & $7.6^{\mathrm{a}} \pm 0.5$ & $7.8^{\mathrm{a}} \pm 0.4$ & $7.0^{\mathrm{bc}} \pm 0.1$ & $7.0^{\mathrm{a}} \pm 0.7$ \\
\hline Olive leaves juice & $6.2^{\mathrm{b}} \pm 0.5$ & $6.8^{\mathrm{a}} \pm 1.0$ & $7.0^{\mathrm{ab}} \pm 0.0$ & $7.0^{\mathrm{a}} \pm 1.0$ & $6.2^{\mathrm{c}} \pm 0.4$ & $6.6^{\mathrm{a}} \pm 1.1$ \\
\hline Green tea leaves & $8.0^{\mathrm{a}} \pm 0.5$ & $7.6^{\mathrm{a}} \pm 0.5$ & $7.8^{\mathrm{a}} \pm 0.4$ & $8.0^{\mathrm{a}} \pm 0.1$ & $8.4^{\mathrm{a}} \pm 0.5$ & $8.2^{\mathrm{a}} \pm 0.8$ \\
\hline $\mathrm{LSD}=$ & 0.65 & 0.94 & 0.69 & 0.72 & 0.86 & 1.10 \\
\hline
\end{tabular}

Data are expressed as mean \pm SD. Values followed by the same letter are not significantly different $(\mathrm{p}<0.05)$. The potato chip samples were rated on a 10-point scale (1,2: bad,3,4: poor,5,6: fair,7,8: good and 9,10: excellent)

\section{CONCLUSION}

Results of current investigation showed that blanching of potato chips in hot water $\left(65\right.$ and $\left.85^{\circ} \mathrm{C}\right)$ or solutions containing $0.05 \mathrm{M}$ citric acid, $0.1 \mathrm{M} \mathrm{CaCl}_{2}$ or $\mathrm{NaCl}, 0.1 \mathrm{M}$ glycine, L-glutamine or L-cysteine reduced significantly acrylamide formation of potato chips by $90.40,88.88,90.40,73.58,76.91,85.20$ and $76.96 \%$ respectively. Soaking of potato slices in water or different solutions caused significant decrease in the formation of acrylamide. Potato slices soaked in 0.01 and $0.05 \mathrm{M}$ of Citric acid and $0.3 \mathrm{M}$ of acetic acid had significantly the lowest values of acrylamide 50, 60 and 190 $\mu \mathrm{g} \mathrm{Kg}^{-1}$ of fried potato. Soaking in phenolic acid solutions for $60 \mathrm{~min}$ resulted in significant reductions in the formation of acrylamide of potato chips. These reductions ranged from 31.81 to $98.03 \%$. Soaking in crude, semipurified asparaginase solutions, blanching in hot water plus immersing in the enzyme solutions and soaking in phenolic acid solutions caused significant reduction in the formation of acrylamide of potato chips. Addition of fresh leaves into frying oil significantly influenced acrylamide formation. Oregano, rosemary, bamboo, guava and olive leaves caused the greatest reductions. Potato slices blanched in distilled water at $65^{\circ} \mathrm{C}, \mathrm{NaCl}, \mathrm{MgCl}_{2}$ and glutamine $(0.1 \mathrm{M})$ had significantly the highest scores of taste, texture, appearance, color, odor and overall acceptability. However those blanched in distilled water at $85^{\circ} \mathrm{C}$, citric acid (0.05), Lcysteine $(0.1 \mathrm{M})$ had significantly the lowest values.

\section{REFERENCES}

Baardseth, P., F. Bjerke, B.K. Martinsen and G. Skrede, 2010. Vitamin C, total phenolics and antioxidative activity in tip-cut green beans (Phaseolus vulgaris) and swede rods (Brassica napus var. napobrassica) processed by methods used in catering. J. Sci. Food Agric., 90: 1245-1255. DOI: 10.1002/jsfa.3967
Baltrusaityte, V., P.R. Venskutonis and V. Ceksteryte, 2007. Radical scavenging activity of different floral origin honey and beebread phenolic extracts. Food Chem., 101: 502-514. DOI: 10.1016/j.foodchem.2006.02.007

Bunger, A., P. Moyano and V. Rioseco, 2003. NaCl soaking treatment for improving the quality of french-fried potatoes. Food Res. Int., 36: 161-166. DOI: 10.1016/S0963-9969(02)00131-X

Burits, M. and F. Bucar, 2000. Antioxidant activity of Nigella sativa essential oil. Phytother, Res., 14: 323-328. PMID: 10925395

Carpenter, R.P., D.H. Lyon, T.A. Hasdell, 2000. Guidelines For Sensory Analysis in Food Product Development and Quality Control. 2nd Edn., Springer, Gaithersburg: Aspen Publisher, ISBN-10: 9780834216426, pp: 210.

Chayabutra, C. and L.K. Ju, 2000. Degradation of nhexadecane and its metabolites by pseudomonas aeruginosa under microaerobic and anaerobic denitrifying conditions. Applied Environ. Microbiol., 66: 493-498. DOI: 10.1128/AEM.66.2.493-498.2000

Ciesarova, Z., E. Kiss and E. Kolek, 2006. Study of factors affecting acrylamide levels in model systems. Czech J. Food Sci., 24: 133-137.

Claeys, W.L., K.D. Vleeschouwer and M.E. Hendrickx, 2005. Effect of amino acids on acrylamide formation and elimination kinetics. Biotechnol. Progress, 21: 1525-1530. DOI: 10.1021/bp050194s

Cuendet, M., K. Hostettmann, O. Potterat and W. Dyatmiko, 1997. Iridoid glucosides with free radical scavenging properties from Fagraea blumei. Helvetica Chim. Acta, 80: 1144-1152. DOI: 10.1002/hlca.19970800411 
Delgado-Andrade, C., I. Seiquer, R. Nieto and M.P. Navarro, 2004. Effects of heated glucose-lysine and glucose-methionine model-systems on mineral solubility. Food Chem., 87: 329-337. DOI: 10.1016/j.foodchem.2003.12.002

El-Bessoumy, A.A., S. Mohamed and M. Jehan, 2004. Production, isolation and purification of $1-$ asparaginase from pseudomonas aeruginosa 50071 using solid-state fermentation. Korean Soc. Biochem. Mol. Biol., 37: 387-393. DOI: 10.5483/BMBRep.2004.37.4.387

Fennell, T.R., S.C.J. Sumner, R.W. Snyder, J. Burgess and R. Spicer et al., 2005. Metabolism and hemoglobin adduct formation of acrylamide in humans. Toxicol. Sci., 85: 447-459. DOI: 10.1093/toxsci/kfi069

Fiselier, K., K. Grob and A. Pfefferle, 2004. Brown potato croquettes low in acrylamide by coating with egg/breadcrumbs. Eur. Food Res. Technol., 219: 111-115. DOI: 10.1007/s00217-004-0925-2

Franke, K., M. Sell and E.H. Reimerdes, 2005. Quality related minimization of acrylamide formation-An integrated approach. Chem. Safety Acrylamide Food, 561: 357-369. DOI:10.1007/0-387-24980X_27

Friedman, M. and C.E. Levin, 2008. Review of methods for the reduction of dietary content and toxicity of acrylamide. J. Agric. Food Chem., 56: 6113-6140. DOI: $10.1021 /$ jf0730486

Friedman, M., 1978. Inhibition of lysinoalanine synthesis by protein acylation. Nutrit. Improv. Food Feed Proteins, 105: 613-648. DOI: 10.1007/978-1-46843366-1 30

Friedman, M., 2003. Chemistry, biochemistry and safety of acrylamide. A review. J. Agric. Food Chem., 51: 4504-4526. DOI: $10.1021 / \mathrm{jf030204+}$

Geng, Z., P. Wang and A. Liu, 2010. Determination of acrylamide in starch-based foods by hplc with precolumn ultraviolet derivatization. J. Chromatogr. Sci., 49: 818-824. DOI: 10.1093/chrsci/49.10.818

Gokmen, V. and H.Z. Senyuva, 2007. Acrylamide formation is prevented by divalent cations during the Maillard reaction. Food Chem., 103: 196-203. DOI: 10.1016/j.foodchem.2006.08.011

Gomez, K.A. and A.A. Gomez, 1984. Statistical Procedures for Agricultural Research. 2nd Edn., IRRI, New York, ISBN-10: 0471879312, pp: 680.
Haase, N.U., B. Matthaus and K. Vosmann, 2003. Acrylamide formation in foodstuffs-minimising strategies for potato crisps. Deutsche LebensmittelRundschau, 99: 87-90.

Hedegaard, R.V., K. Granby, H. Frandsen, J. Thygesen and L.H. Skibsted, 2008. Acrylamide in bread. Effect of prooxidants and antioxidants. Eur. Food Res. Technol., 227: 519-525. DOI: 10.1007/s00217007-0750-5

Hurrel, R.F. and P.A. Finot, 1984. Nutritional consequences of the reactions between proteins and oxidized polyphenolic acids. Nutrit. Toxicol. Aspects Food Safety, 177: 423-427. DOI: 10.1007/978-1-4684-4790-3 20

Jayaprakasha, G.K., T. Selvi and K.K. Sakariah, 2003. Antibacterial and antioxidant activities of grape (Vitis vinifera) seed extracts. Food Res. Int., 36: 117-122. DOI: 10.1016/S0963-9969(02)00116-3

Jung, M.Y., D.S. Choi and J.W. Ju, 2003. A novel technique for limitation of acrylamide formation in fried and baked corn chips and in French fries. J. Food Sci., 68: 1287-1290. DOI: 10.1111/j.13652621.2003.tb09641.x

Kim, C.T., E.S. Hwang and H.J...Lee, 2005. Reducing acrylamide in fried snack products by adding amino acids. J. Food Sci., 70: C354-C358. DOI: 10.1111/j.1365-2621.2005.tb09966.X

Kita, A., E., Brathen, S.H., Knutsen and T. Wicklund, 2004. Effective ways of decreasing acrylamide content in potato crisps during processing. J. Agric. Food Chem., 52: 7011-7016. DOI: 10.1021/jf049269i

Levine, R.A. and R.E. Smith, 2005. Sources of variability of acrylamide levels in a cracker model. J. Agric. Food Chem., 53: 4410-4416. DOI: $10.1021 / \mathrm{jf0} 47887 \mathrm{t}$

Lindsay, R.C. and S. Jang, 2005. Chemical intervention strategies for substantial suppression of acrylamide formation in fried potato products. Chem. Safety Acrylamide Food, 561: 393-404. DOI: 10.1007/0387-24980-X_30

Mestdagh, F., J. Maertens, T. Cucu, K. Delporte and C.V. Peteghem, 2007. Impact of additives to lower the formation of acrylamide in a potato model system through $\mathrm{pH}$ reduction and other mechanisms. Food Chem., 107: 26-31. DOI: 10.1016/j.foodchem.2007.07.013

Mottram, D.S. and B.L. Wedzicha, 2002. Acrylamide is formed in the maillard reaction. Nature, 419: 448449. DOI: $10.1038 / 419448 a$ 
O’Brien, J. and P.A. Morrissey, 1997. Metal ion complexation by products of the maillard reaction. Food Chem., 58: 17-27. DOI: 10.1016/S03088146(96)00162-8

Ou, S.Y., Q.L. Lin, Y. Wang, C.H. Huang and X.S. Huang et al., 2004. Effect of several additives on destroying acrylamide. China Oils Fats, 29: 61-63.

Park, Y., H. Yang, J. M. Storkson, K.J. Albright and R.C. Lindsay et al., 2005. Controlling acrylamide in French fry and potato chip models and a mathematical model of acrylamide formation. Chem. Safety Acrylamide Food, 561: 343-356. DOI: 10.1007/0-387-24980-X_26

Pedreschi, F. and P.C. Moyano, 2005. Effect of predrying on texture and oil uptake of potato chips. LWT-Food Sci. Technol., 38: 599-604. DOI: 10.1016/j.lwt.2004.08.008

Pedreschi, F., K. Kaack and K. Granby, 2004. Reduction of acrylamide formation in potato slices during frying. LWT-Food Sci. Technol., 37: 679-685. DOI: 10.1016/j.lwt.2004.03.001

Pedreschi, F., K. Kaack and K. Granby, 2006. Acrylamide content and color development in fried potato strips. Food Res. Int., 39: 40-46. DOI: 10.1016/j.foodres.2005.06.001

Pedreschi, F., K. Kaack, K. Granby and E. Troncoso, 2007. Acrylamide reduction under different pretreatments in french fries. J. Food Eng., 79: 12871294. DOI: $10.1016 /$ j.jfoodeng.2006.04.014

Rimac-Brncic, S., V. Lelas, D. Rade and B. Simundic, 2004. Decreasing of oil absorption in potato strips during deep fat frying. J. Food Eng., 64: 237-241. DOI: $10.1016 /$ j.jfoodeng.2003.10.006
Stadler, R.H., F. Robert, S. Riediker, N. Varga and T. Davidek et al., 2004. In-depth mechanistic study on the formation of acrylamide and other vinylogous compounds by the Maillard reaction. J. Agric. Food Chem., 52: 5550-5558. DOI: 10.1021/jf0495486

Tritscher, A.M., 2004. Human health risk assessment of processing-related compounds in food. Toxicol. Lett., 149: 177-186. DOI: 10.1016/j.toxlet.2003.12.059

Varela, P., A. Salvador and S.M. Fiszman, 2007. The use of calcium chloride in minimally processed apples: A sensory approach. Eur. Food Res. Technol., 224: 461-467. DOI: 10.1007/s00217-006-0344-7

Vass, M., T.M. Amrein, B. Schonbachler, F. Escher and R. Amado, 2004. Ways to reduce the acrylamide formation in cracker products. Czech J. Food Sci., 22: $19-21$.

Vattem, D.A. and K. Shetty, 2003. Acrylamide in food: A model for mechanism of formation and its reduction. Innovative Food Sci. Emerg. Technol., 4: 331-338. DOI: 10.1016/S1466-8564(03)00033-X

WHO, 2005. Preventing Chronic Diseases: A Vital Investment. 1st Edn., World Health Organization, Geneva, ISBN-10: 9241563001, pp: 182.

Yaylayan, V.A., A. Wnorowski and C.P. Locas, 2003. Why asparagine needs carbohydrates to generate acrylamide. J. Agric. Food Chem., 51: 1753-1757. DOI: $10.1021 /$ jf0261506

Zhang, Y. and Y. Zhang, 2007. Formation and reduction of acrylamide in maillard reaction: A review based on the current state of knowledge. Critical Rev. Food Sci. Nutrit., 47: 521-542. DOI: $10.1080 / 10408390600920070$ 